\title{
Uterine Souffle
}

National Cancer Institute

\section{Source}

National Cancer Institute. Uterine Souffle. NCI Thesaurus. Code C92910.

A soft murmur heard in auscultating a pregnant uterus. It is caused by the increased vascularity of pregnancy. 